\title{
Abnormal intra-thoracic fat distribution in patients with metabolic syndrome with and without myocardial infarction
}

\author{
Umjeet S Jolly ${ }^{1 *}$, Matthew Brymer ${ }^{2}$, Nowell Fine ${ }^{3}$, Charles McKenzie ${ }^{1}$, Tisha Joy ${ }^{1}$, Maria Drangova ${ }^{1}$, James A White ${ }^{3}$ \\ From 2011 SCMR/Euro CMR Joint Scientific Sessions \\ Nice, France. 3-6 February 2011
}

\section{Introduction}

Adipose distribution is a useful tool for cardiovascular risk stratification when compared to body mass index (BMI) alone. We sought to compare intra-thoracic fat distribution in patients with or without metabolic syndrome (MetS), and to identify differences in those with and without evidence of prior myocardial infarction (MI), as determined by delayed enhancement (DE) MRI.

\section{Methods}

A total of 110 consecutive patients referred for DE MRI suspected of having either MetS or prior MI were enrolled and received a thoracic fat survey using HASTE imaging. This was performed throughout the full thorax in the sagittal plane at $10 \mathrm{~mm}$ intervals (10mm slice thickness, zero gap) during shallow breathing. Off-line signal threshold analysis (CMR42, Circle Cardiovascular Inc. Calgary) was used to determine intra-thoracic fat volume using a $>10$ SD signal threshold above the mean of 4 skeletal muscle sample volumes. Total intra-thoracic fat volume was indexed to body surface area to provide a measure of relative fat distribution. Patients were stratified into 3 disease groups according to stringent criteria; A) MetS+/MI-, B) MetS-/MI+, and C) MetS+/MI+. MetS was defined as any 3 of the following 5 criteria: BMI $>30 \mathrm{~kg} / \mathrm{m}^{2}$, serum triglycerides $\geq 1.7 \mathrm{mmol} / \mathrm{L}, \mathrm{HDL}-\mathrm{C}<1.0 \mathrm{mmol} / \mathrm{L}$ for men or HDL-C $<1.3 \mathrm{mmol} / \mathrm{L}$ for women, HgbA1c $\geq 6.5 \%$, SBP $\geq 130 \mathrm{mmHg}$ or DBP $\geq 85 \mathrm{mmHg}$. MI was defined as the presence of subendocardial-based DE in a coronary artery distribution. 16 volunteers were also

\footnotetext{
${ }^{1}$ University of Western Ontario, London, ON, Canada

Full list of author information is available at the end of the article
}

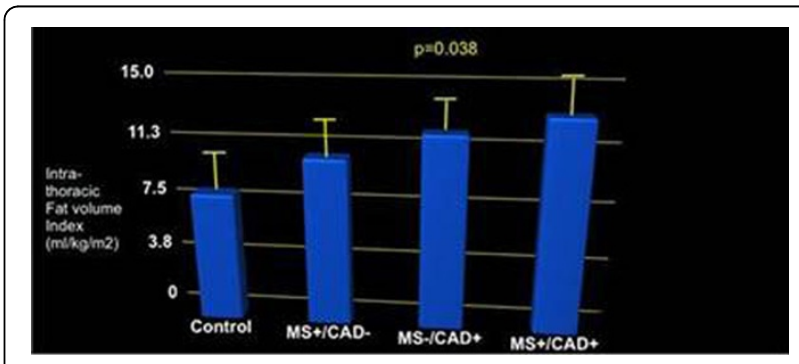

Figure 1 Indexed intra-thoracic fat volume including BMI. There is an incremental increase of indexed intra-thoracic fat volume with MetS and prior MI.

imaged to provide a normal reference cohort. Data was analyzed using ANOVA statistical analysis.

\section{Results}

In total 80 of the 110 -screened patients met disease criteria. All 16 volunteers completed the imaging protocol (total $\mathrm{N}=96)$. Mean age was $59.8 \pm 12.5$ years $(78 \%$ male, $71 \%$ Caucasian). 26 patients (32\%) were identified as MetS+/MI-, $33(41 \%)$ as MetS-/MI+, and $21(26 \%)$ as MetS+/MI+. All 16 volunteers were MetS-/MI-. The intra-thoracic fat distribution was significantly different among the groups, as follows; MetS+/MI+ was $13.3 \pm 2.0$ $\mathrm{ml} / \mathrm{kg} / \mathrm{m}^{2}$, MetS- $/ \mathrm{MI}+$ was $12.15 \pm 2.06 \mathrm{ml} / \mathrm{kg} / \mathrm{m}^{2}$, MetS $+/ \mathrm{MI}$ - was $10.57 \pm 2.37 \mathrm{ml} / \mathrm{kg} / \mathrm{m}^{2}$ and controls were $8.16 \pm 2.29 \mathrm{ml} / \mathrm{kg} / \mathrm{m}^{2}(\mathrm{p}$ value $=0.038)($ See Figure 1$)$.

\section{Conclusion}

Indexed intra-thoracic fat volume is elevated relative to healthy controls in patients with either MetS or prior MI, and more significantly elevated in patients with both MetS and MI. This may be an important variable 
for the prediction of ischemic cardiovascular events, especially in patients with MetS. Prospective outcomesbased cohort studies are warranted to explore this potential.

\section{Author details}

${ }^{1}$ University of Western Ontario, London, ON, Canada. ${ }^{2}$ Biomedical Imaging Research Centre (BIRC), London, ON, Canada. ${ }^{3}$ London Health Sciences

Centre, London, ON, Canada.

Published: 2 February 2011

doi:10.1186/1532-429X-13-S1-P166

Cite this article as: Jolly et al:: Abnormal intra-thoracic fat distribution in patients with metabolic syndrome with and without myocardial

infarction. Journal of Cardiovascular Magnetic Resonance 2011 13(Suppl 1):

P166.

Submit your next manuscript to BioMed Central and take full advantage of:

- Convenient online submission

- Thorough peer review

- No space constraints or color figure charges

- Immediate publication on acceptance

- Inclusion in PubMed, CAS, Scopus and Google Scholar

- Research which is freely available for redistribution 